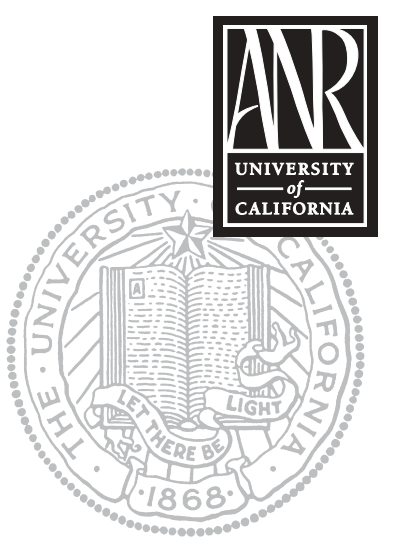

UNIVERSITY OF CALIFORNIA

Division of Agriculture and Natural Resources http://anrcatalog.ucdavis.edu

\title{
Stages of the Cottony Cushion Scale (Icerya purchasi) and its Natural Enemy, the Vedalia Beetle (Rodolia cardinalis)
}

BETH GRAFTON-CARDWELL is IPM Specialist and Research Entomologist, Department of Entomology, University of California, Riverside, and is stationed at the Kearney Agricultural Center in Parlier.

\section{Stages of the Cottony Cushion Scale (Icerya purchasi)}

Cottony cushion scale life cycle is 3 months.

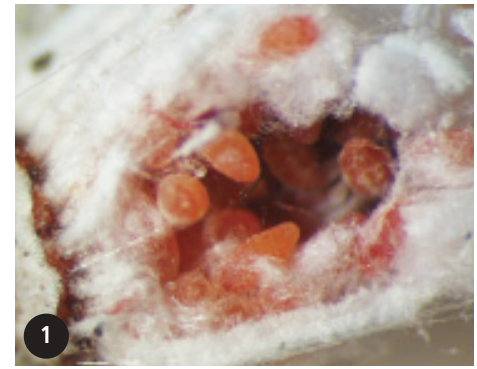

200 to 400 red eggs inside the egg sac of the female scale (7 days to hatch)

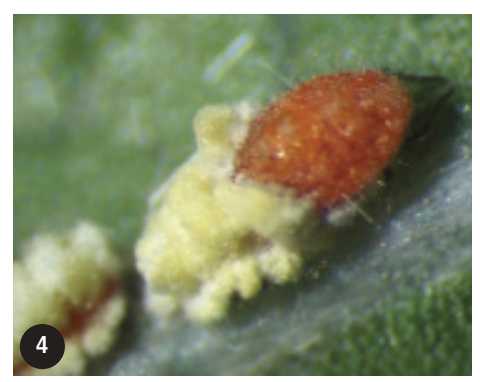

Second instar nymph emerging from the white molt shell

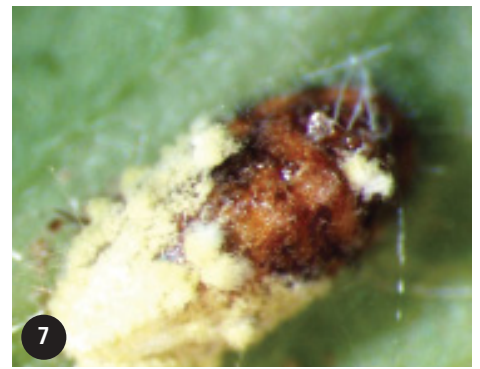

Third instar nymph emerging from the white molt shell

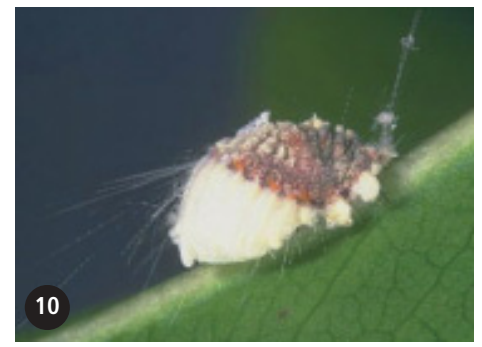

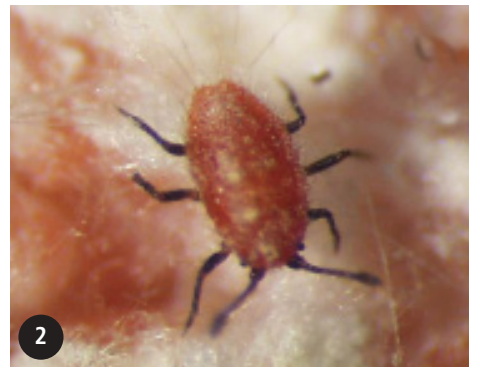

First instar crawler; note the black legs and antennae (1 week)

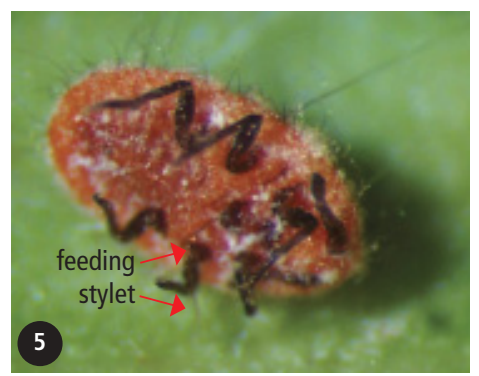

Second instar nymph underside Note the thread-like feeding tube (stylet) attached to the leaf.

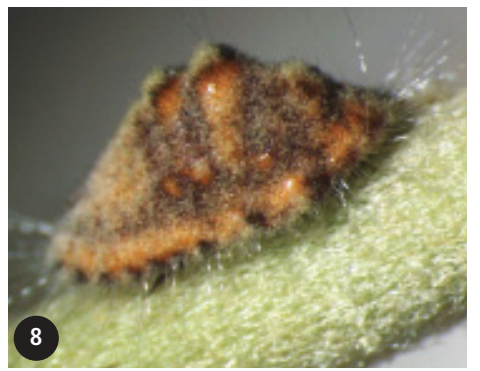

Third instar nymph

Note the long hairs grouped in tufts. (2 to 3 weeks)

Adult female

The more cottony material she has, the more eggs inside her egg sac.

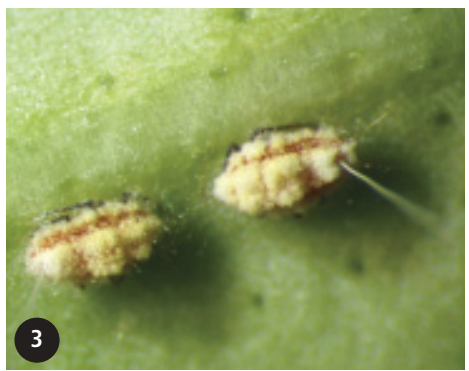

First instar nymphs settled down and producing a cottony substance ( 2 to 3 weeks)

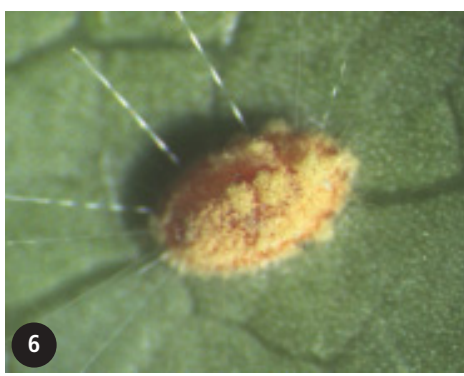

Second instar nymph

The amount of cottony substance increases with age. (2 to 3 weeks)

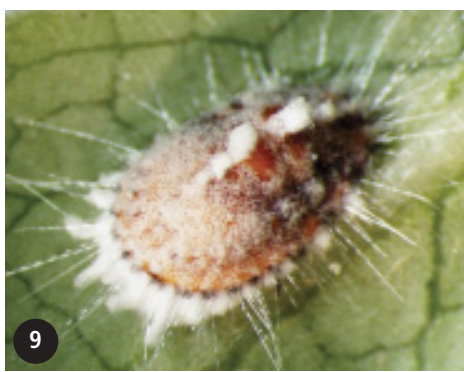

Young female

(4 weeks until egg production) 


\section{Vedalia Beetle (Rodolia cardinalis)}

Natural enemy of the cottony cushion scale.

Vedalia beetle life cycle is 3 to 4 weeks from egg to adult.

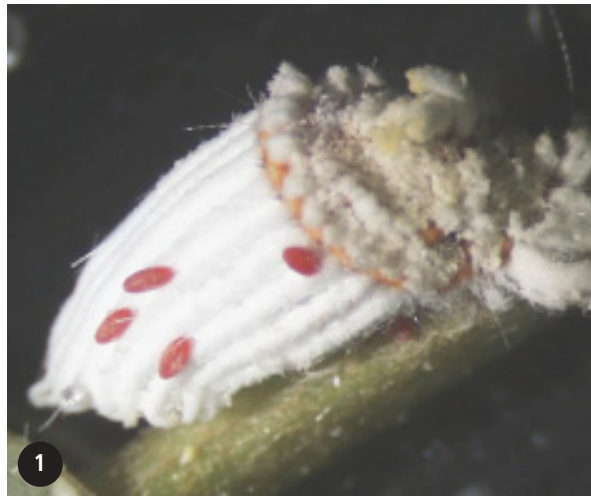

Red vedalia eggs on the outside of an adult scale

(4 to 7 days to vedalia hatch)

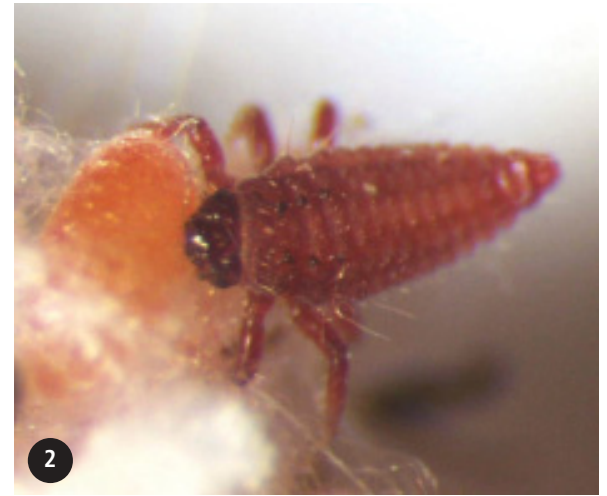

First instar vedalia larva feeding on a scale egg

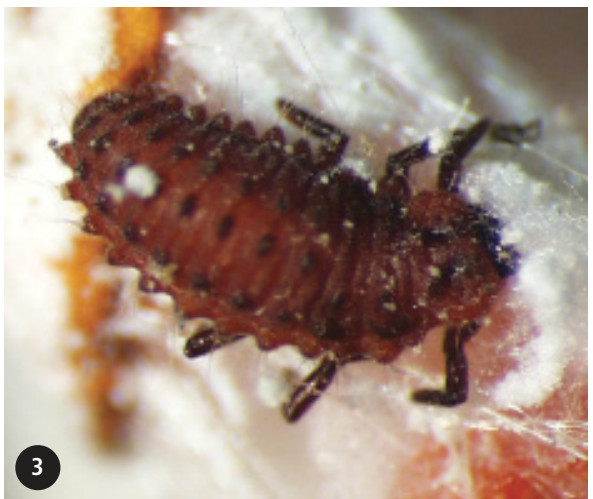

Second instar vedalia larva burrowing into a cottony cushion scale egg sac

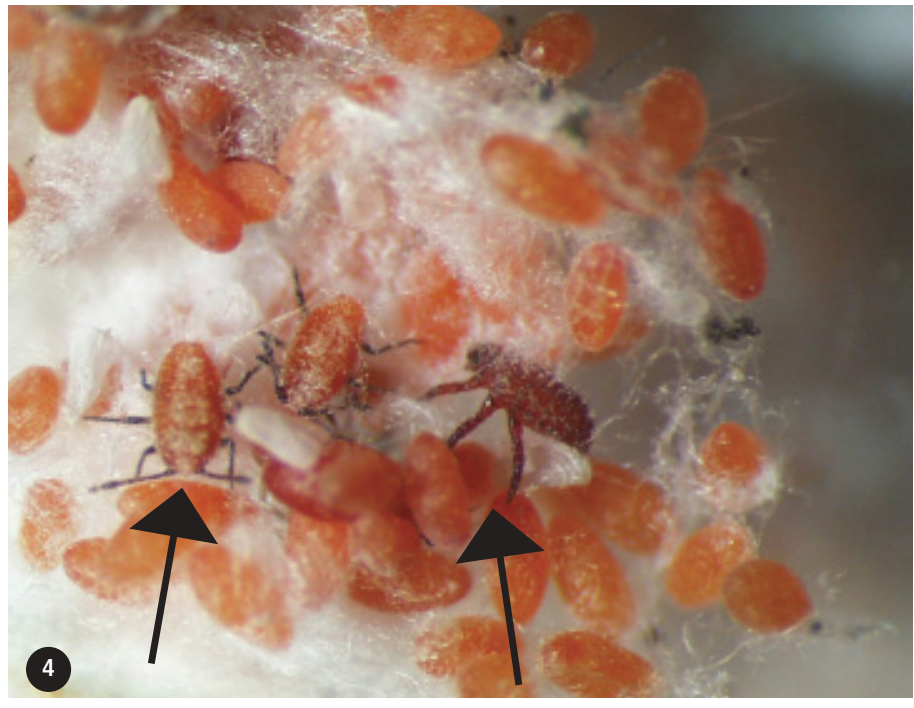

Scale crawler compared to a vedalia larva Note the scale has black legs and black antennae, whereas the vedalia larva has red legs and no visible antennae.

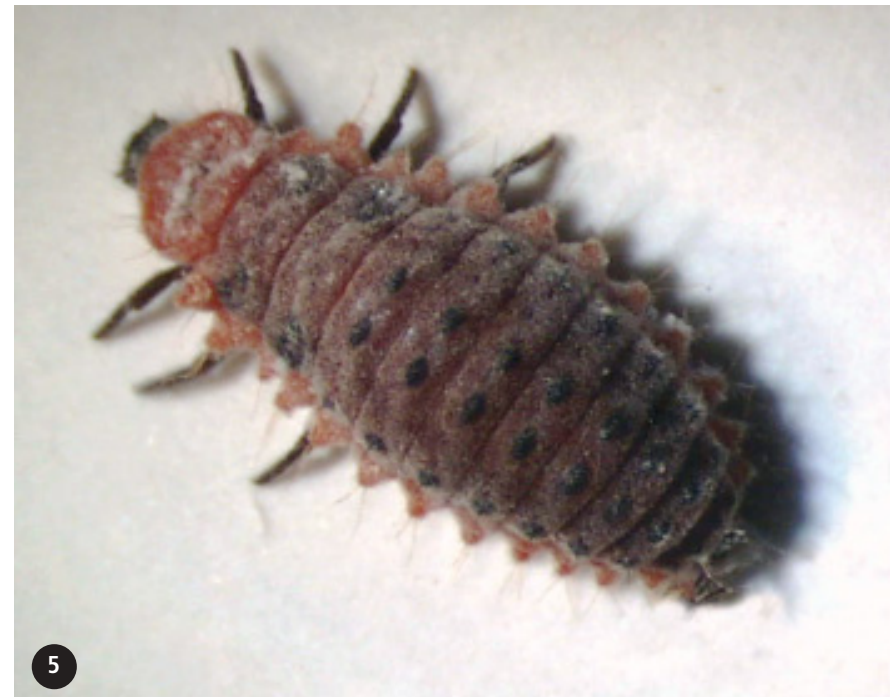

Late instar vedalia larva

(10 to 20 days for all four larval stages to develop)

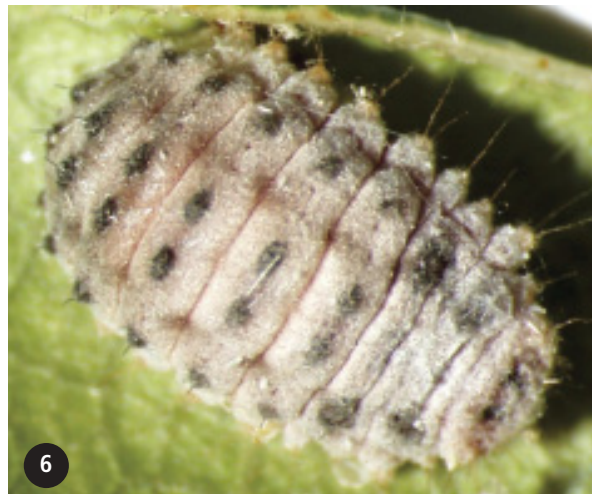

Fourth instar vedalia larva

Larvae attach themselves to a leaf and stop feeding just before pupation.

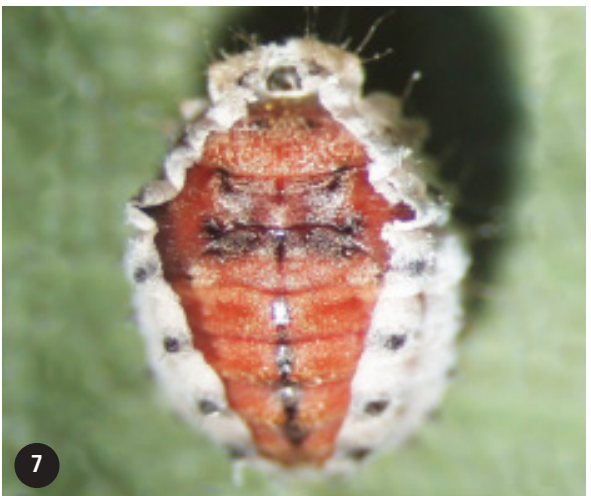

\section{Vedalia pupa}

A healthy pupa should move when touched. (1 week until adult emergence)

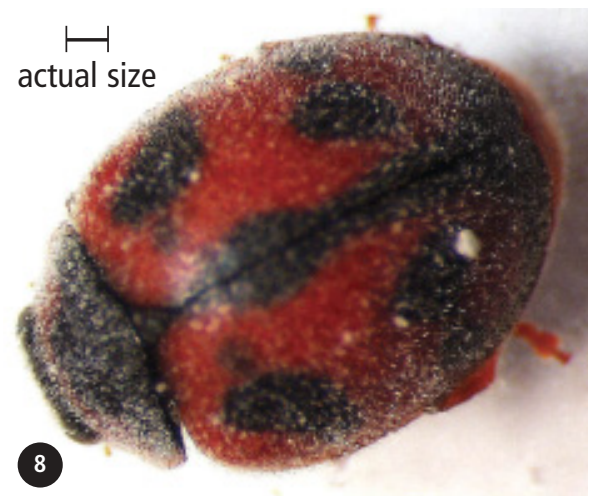

Adult vedalia beetle

(Lives 1 to 3 months and lays 100 to 200 eggs) 


\section{FOR MORE INFORMATION}

You'll find detailed information on many aspects of field crop production and resource conservation in these titles and in other publications, slide sets, CDs, and videos from UC ANR:

Natural Enemies Are Your Allies!, poster 21496

Natural Enemies Handbook, publication 3386

Pests of the Garden and Small Farm, publication 3332

To order these products, visit our online catalog at http://anrcatalog.ucdavis.edu. You can also place orders by mail, phone, or fax, or request a printed catalog of publications, slide sets, and videos from

University of California Agriculture and Natural Resources Communication Services 6701 San Pablo Avenue, 2nd Floor

Oakland, California 94608-1239

Telephone: (800) 994-8849 or (510) 642-2431

FAX: (510) 643-5470

E-mail inquiries: danrcs@ucdavis.edu

An electronic version of this publication is available on the ANR Communication Services Web site at http://anrcatalog.ucdavis.edu.

\section{Publication 8051}

(C) 2002 by the Regents of the University of California, Division of Agriculture and Natural Resources. All rights reserved.

The University of California prohibits discrimination against or harassment of any person employed by or seeking employment with the University on the basis of race, color, national origin, religion, sex, physical or mental disability, medical condition (cancer-related or genetic characteristics), ancestry, marital status, age, sexual orientation, citizenship, or status as a covered veteran (special disabled veteran, Vietnam-era veteran or any other veteran who served on active duty during a war or in a campaign or expedition for which a campaign badge has been authorized).

University Policy is intended to be consistent with the provisions of applicable State and Federal laws.

Inquiries regarding the University's nondiscrimination policies may be directed to the Affirmative Action/Staff Personnel Services Director, University of California, Agriculture and Natural Resources, 300 Lakeside Drive, 6th Floor, Oakland, CA 94612-3550 (510) 987-0096. For information on downloading this publication, call (530) 754-5112.

pr-9/02-WJC/CR

ISBN 978-1-60107-229-0 